\title{
Improving the Preparation of Iranian Urban Development Plans: Lessons Learned from Other Experiences
}

\author{
Mohammad Javad Maghsoodi Tilaki ${ }^{1}$, Azizi Bahauddin ${ }^{2}$, Aldrin Abdullah ${ }^{2} \&$ Massoomeh Hedayati Marzbali $^{2}$ \\ ${ }^{1}$ Department of Urban Planning, Payame Noor University, PO BOX 19395-3697 Tehran, Iran \\ ${ }^{2}$ School of Housing, Building \& Planning, Universiti Sains Malaysia, 11800 Penang, Malaysia \\ Corresponding: Mohammad Javad Maghsoodi Tilaki, Department of Urban Planning, Payame Noor University, \\ PO BOX 19395-3697 Tehran, Iran. Tel: 98-601-7405-8454. E-mail: maghsoodi@usm.my
}

\author{
Received: May 5, $2014 \quad$ Accepted: May 20, $2014 \quad$ Online Published: June 25, 2014 \\ doi:10.5539/mas.v8n4p144 URL: http://dx.doi.org/10.5539/mas.v8n4p144
}

\begin{abstract}
The rapid urbanization process all over the world has raised the need to employ more satisfactory urban development approaches; these are especially recognized and declared in developing countries. This paper attempts to indicate what achievable ways may improve the current urban development plans based on the comprehensive planning method in Iran. In order to achieve this objective, this paper reviews qualitatively the urban planning in Iran and assesses its urban development plans. Ultimately, appropriate measures are presented in order to suggest how the defects found in the current Iranian urban development plans may be corrected by employing the lessons learned from practical examples recorded in other selected countries. The primary data was collected by means of semi-structured interviews from decision making and decision taking processes in Iran. In conclusion, this article suggests that the identified defects of urban development plans in Iran may be improved by adapting to the most recent universal concepts of urban planning. In other words, Iranian urban planning should be distanced from political decisions and instead motivated as a technical process in the government structure.
\end{abstract}

Keywords: Urban planning, comprehensive planning, urban development plan, local government, Iran

\section{Introduction}

The opinions of both practitioners and planning theoreticians are considered in the craft of urban planning in Iran with, Upper-Middle income economies and rapid urbanization country in the Southwest Asia (World Bank, 2011). In recent years, rapid urbanization as a global challenge has raised Iranian cities' urban population of the 70 percent (Statistical Center of Iran, 2006). Furthermore, in Iran the land plays a significant role for the built environment, habitation and settlement development due to geographical restriction for people living. Iran has experienced 10 national development plans since 1942, including country visions in major aspects of the education, health, construction, energy, economy, social related issues, and national security's development. By the end of 1972, a requirement to reinstate urban planning as a instrument to manage urban development was introduced in the country (Tang, 2011) as the Iranian society was moving towards an increased modernization and industrialization under the effects of varied policies of national development plans (Ferdowsian, 2002). A master plan was introduced in the 1960's through the second national development plan. Earlier master plans were prepared for various Iranian cities in the third national development plans (1963-1967) based on the comprehensive planning method (Kamrava, 2007).

Initial master plans had not considered all aspects of the cities' growth, consequently promoting urban land speculation, physical expansion, and the development of suburbs (Clark, 1981). Organizationally, urban development's control has been considered as a more remarkable situation in the administrative hierarchy's process, mainly sustained by the oil income which had initially contributed to three quarters of the annual government's budget, and was then injected into the cities' expenditures (Karshenas, 1990; Ziari, 2006). Concisely, Pahlavi monarchy has emphasized on urban planning conducted by using master plans, when the results of governmental policies towards industrialization and modernization caused instead evident major structural defects in the cities (Ferdowsian, 2002; Madanipour, 2003).

Generally, the executive and provisional structure of the government was disorganized due to the specific 
situation of the country throughout the 1980's, such as the Islamic revolution, and the Iraqi-Iranian war. The Parliament was responsible for the main legislation, while the executive power was administered by the Council of Ministers (Cabinet). There were governmental authorities based on the country's subdivision at the local levels of the public administration. All the legislative and also a substantial part of the administrative powers were limited to the central institutions of the state, making Iran's government a centralized one. Moreover, the Ministry of Housing and Urban Development (MHUD) is responsible for the preparation, confirmation, and revision of master plans in all Iranian cities; however they are executed by the single municipalities (MHUD, 2006).

Iran's urban planning has been refocused after the end of the war in the late 1980s (Kamrava, 2007). Different transformations in the administrative and legislative aspects have been designed towards an increased efficiency in urban planning, in order to reduce the cities' problems when their deficiencies were expanded. Consequently, there has been a great increase in the literature investigating the different facets of the Iranian urban development process. Perhaps surprisingly, however, as of yet there is a lack of substantial literature reviews covering the urban development plans in Iran. Additionally, current research has examined only a specific view of urban planning in Iran; nevertheless, the urban development plans' improvement has still not been the object of adequate research. In order to fill such a gap, this paper attempts to indicate the deficiencies of urban development plans in Iran and suggest various solutions to help improve the current situation based on the government's features, abilities and weakness of planning process in Iran.

\section{Methodology}

The methodology of this study consists of a qualitative examination of the urban development plans' preparation in Iran in order to indicate its potential deficiencies in the last fifty years, and then suggest appropriate measures to help improve the current situation based on the varied internationally innovated approaches in other selected countries. Semi-structured interviews have been conducted in order to identify the inefficiencies of Iran's urban development plans. In this respect, twenty five Iranian persons who are responsible for the decision making and decision taking processes of urban planning were selected as interviewees, including some representatives of the national and local authorities, and development-related Institutions.

NVivo 8 was employed as a Qualitative Research Software (QRS) in order to analyze this paper's primary data. The secondary data, constituted by papers, books, official documents, and government reports, was collected from various scientific sources such as libraries, governmental intuitions such as MHUD, and overseas governmental resources like the Japanese Ministry of Land, Infrastructure, Transport and Tourism (JMLITT), and other international organizations such as the United Nations' agency for human settlements (UN-Habitat) and the Asian Development Bank (ADB). It is hoped that this paper will be significant towards the facilitation and rectification of the aforementioned instability in the current Iranian urban planning process. This paper's literature review will be used as a background for a better-informed analysis of urban development processes in Iran.

The paper is structured as follows: firstly, a framework is established serving as a configuration to individuate the selected countries before they are categorized according to the sufficiency of their own urban development plans. The second part explains the background of urban development planning in the nine selected countries. The third part outlines the major issues of this paper. These issues represent major inefficiencies of urban development plans. This part is the result of the primary data's extraction as collected from the interviews. The fourth part presents suggestions to unravel the obstacles of Iranian urban development plans based on the functions which have been previously achieved in the other selected countries. All the arguments are summarized in the conclusion.

\section{Establishment of the Study's Framework}

Practically, a review of worldwide practices in urban development control may be an impossible task due to the varying degree of abilities, requirements, situations and goals. Hence, this paper only selects and focuses on nine countries to help achieve comprehensive reviews concerning the preparation of urban development plans. The countries are chosen in order to cover a broad variety of geologic locations, economic situations, i.e. developed/developing countries (Chaker et al., 2006), and urbanization evolution, as well as different urban development mechanisms and approaches pending data availability as indicated in Table 1 and based on the satisfactory abstraction and clarification. 
Table 1. Review of the selected countries and highlighted features in urban planning

\begin{tabular}{|c|c|c|c|c|}
\hline No & Country & $\begin{array}{l}\text { Location } \\
\text { geography }\end{array}$ & $\begin{array}{l}\text { Economic } \\
\text { categories }\end{array}$ & Highlighted features in urban planning \\
\hline 1 & $\begin{array}{l}\text { The United } \\
\text { Kingdom }\end{array}$ & $\begin{array}{l}\text { Northwest } \\
\text { Europe }\end{array}$ & $\begin{array}{l}\text { High } \\
\text { income }\end{array}$ & $\begin{array}{l}\text { Pioneer in urban planning; } \\
\text { Replace method's discretion as zoning; } \\
\text { Upgrading urban planning system toward more public } \\
\text { participation. }\end{array}$ \\
\hline 2 & $\begin{array}{l}\text { The United } \\
\text { State }\end{array}$ & $\begin{array}{l}\text { North } \\
\text { America }\end{array}$ & $\begin{array}{l}\text { High } \\
\text { income }\end{array}$ & $\begin{array}{l}\text { Employing various methods in urban planning; } \\
\text { Decentralizations in levels of planning; } \\
\text { The specific role of people in urban development plans. }\end{array}$ \\
\hline 3 & France & $\begin{array}{l}\text { Southern } \\
\text { Europe }\end{array}$ & $\begin{array}{l}\text { High } \\
\text { income }\end{array}$ & $\begin{array}{l}\text { Expansion of urban planning; } \\
\text { Successful decentralization in preparation and implementation of } \\
\text { urban development plan. }\end{array}$ \\
\hline 4 & Germany & $\begin{array}{l}\text { Central } \\
\text { Europe }\end{array}$ & $\begin{array}{l}\text { High } \\
\text { income }\end{array}$ & $\begin{array}{l}\text { Stronger legal backing for urban development plans; } \\
\text { Inflexible urban development plans. }\end{array}$ \\
\hline 5 & Denmark & $\begin{array}{l}\text { Northern } \\
\text { Europe }\end{array}$ & $\begin{array}{l}\text { High } \\
\text { income }\end{array}$ & $\begin{array}{l}\text { Considerable decentralization in preparation and implementation } \\
\text { of urban development plans; } \\
\text { Emphasize on environment quality in urban development plans; } \\
\text { Appropriate consideration to public benefits in urban } \\
\text { development plans. }\end{array}$ \\
\hline 6 & Japan & $\begin{array}{l}\text { Eastern } \\
\text { Asia }\end{array}$ & $\begin{array}{l}\text { High } \\
\text { income }\end{array}$ & $\begin{array}{l}\text { Industrialization and shortage of adequate urban land; } \\
\text { The widespread use of land readjustment. }\end{array}$ \\
\hline 7 & Netherland & $\begin{array}{l}\text { North } \\
\text { West } \\
\text { Europe }\end{array}$ & $\begin{array}{l}\text { High } \\
\text { income }\end{array}$ & $\begin{array}{l}\text { Pioneer in urban planning; } \\
\text { Inflexible urban development plans; } \\
\text { Decentralization in preparation and implementation of urban } \\
\text { development plan. }\end{array}$ \\
\hline 8 & Malaysia & $\begin{array}{l}\text { Southeast } \\
\text { Asia }\end{array}$ & $\begin{array}{l}\text { Upper } \\
\text { Middle } \\
\text { income }\end{array}$ & $\begin{array}{l}\text { Rapid urbanization growth; } \\
\text { Focusing on preparation and implementation of urban } \\
\text { development plans despite limitation of governmental financial } \\
\text { resources; } \\
\text { Establishment of urban planning as subsystem in spatial planning } \\
\text { system; } \\
\text { Adaptation of executive methods with the social, economic, and } \\
\text { legal situation. }\end{array}$ \\
\hline 9 & India & $\begin{array}{l}\text { Southern } \\
\text { Asia, }\end{array}$ & $\begin{array}{l}\text { Low } \\
\text { income }\end{array}$ & $\begin{array}{l}\text { Rapid urbanization growth; } \\
\text { Focusing on preparation and implementation of urban; } \\
\text { development plans despite limitation of governmental financial } \\
\text { resources; } \\
\text { Government effort to reduce housing shortage and prevention of } \\
\text { informal settlements. }\end{array}$ \\
\hline
\end{tabular}

Source: Authors' work.

\section{Concepts of Urban Development Plans}

The review of urban development plans shows that modern urban development plans' inception goes back to Athens Charter in the CIAM (1933) (Mumford, 1992). Some studies have described that physical discipline; social and economic systems should be coordinated in urban planning (Basiago, 1998; De GraafandDewulf, 2010; Fainstein, 1991). Therefore, urban development plans cannot be disconnected from national planning as national planning is recognized as the highest instrument to help establish social and economic ideas in most countries around the world. The experiences of the selected countries reveal that they all have employed national development plans, including the physical-spatial strategies. The national plan has been legally implemented in these particular countries, while has advisory roles in Germany and the Netherlands (Larsson, 2006). In this case, some countries have full coordination between urban and national development plans through regional planning, as in the case of Malaysia (Malaysian Federal Department of Town and Country Planning, 2010). In the United Kingdom, local plans have not connected with regional strategies until year 2004, even if regional strategies and urban planning started to be connected from the same year when the government enacted a Planning Act and 
Compulsory purchase (CPRE, 2011). A review of spatial planning systems in the selected countries has indicated that urban planning has been connected with upper planning at national or regional levels.

In addition, several countries have development plans at county levels where their roles are advisory and not compulsory, as in the case of the Netherlands (Larsson, 2006). In the exceptional case of the United Kingdom, the preparation of a structure plan for the whole country's developmental process is compulsory, as since 2004 a Local Development Framework has been introduced as a unitary plan (CPRE, 2011).

Denmark's experience showed a different system with three levels of planning. The planning authorities are here delegated to different levels due to the country's decentralization policy (Larsson, 2006). In this respect, France has also focused on the decentralization to help raise planning system's efficiencies since 1980. This policy has established a multi-tiered collaboration among the states, regions, local autonomous bodies and inter-communal organs, and consequently regional authorities' roles have been improved in the spatial planning (JMLITT, 2011; Larsson, 2006).

The Netherlands' government has been reducing centralization in urban planning's regulations by distributing more responsibilities to the local governments since 2006. This strategy was preceded under the fundamental amendment of the Spatial Planning Act of 2008. Additionally, decision-making procedures were simplified to help ensure increased effectiveness in the decision-making functions. The central government confirmed the delegation of authority to local governments for the determination of spatial strategies, while these were previously only a responsibility of the central government (Dutch Ministry of Infrastructure and the Environment, 2011).

Since 2005 Denmark, as a Scandinavian country, has also transformed the local planning system which had been transformed by the government from counties into five popularly regional councils' elections, responsible for the conduction of the spatial planning process and the supply of social welfare. This reform emphasized on the decentralization of decision-making process and the increase of public participation. The transformation of municipal plans has been recognized as the key plan in the development process (Danish Ministry of the Environment, 2007). Generally, the recent transformations of the European countries have focused on the achievement of more public participation and high efficiency of decentralization in order to attain more executive powers at the local levels.

In contrast India, being the country with the second largest population in the world, has three administrative levels of government like most other countries including the union, the state, and the local government (Indian Local Government, 2011).

The government of India prepares the national plan, including various strategies in different fields. The Indian national plan is not directly connected with the urban plans, but it affects the master plan through the Five-year Plans, which are prepared by the state government.

Iran has also employed its national plan from 1942 without directly connecting it with the master plan in a strong and systematic manner (Panahandeh et al., 2009). Basically, Iran's national plan is also considered as social, economic and cultural development plans (Ramli \& Azadehdel, 2009). Thus, the spatial aspect of the national plan is not directly emphasized on urban planning, but on other aspects such as human settlements, housing, urban infrastructures, and urban expansion. Furthermore, regional planning has provided a specific condition which has no connection to urban planning (Rahnama, 2008).

However, most countries emphasize local planning as the highest level of planning. So, local planning is supported by strong executive powers at national level and subsequently its continuity is established among the planning levels of countries such as in the case of France and Denmark. By contrast, in Iran those municipalities which are responsible for the implementation of the master plan have various barriers in the exercise of their executive powers due to the lack of urban planning continuity with the national plan.

On the other hand, goals were considered differently among the selected countries. In this perspective, the Malaysian government has defined local plans' missions as guidelines for arranging and organizing the development and administrating decisions while they employ the German Flachennutzurgs Plan (F-plan) as the subcategory of regional plans in an attempt to manage the growth by land use strategies (JMLITT, 2011; Malaysian Federal Department of Town and Country Planning, 2010). In this line, the municipalities of the Netherlands devise land use zoning plans to enhance development based on the national planning (JMLITT, 2011).

Generally, the determination of land use and building construction are the basic roles of urban development plans in the selected countries, however some nations such as Denmark have added the protection of environment as 
an additional task (Danish Ministry of the Environment, 2007). Nevertheless, in the aforementioned countries urban development plans are prepared with transparent, declared roles and intelligible functions. In this way, some countries revealed their local plans' goals through additional detailed planning, such as the United Kingdom, the United States, Germany, Denmark, and Iran.

However, some functions are considered in the urban planning's concepts of selected countries and can be classified in the following categories:

- $\quad$ Coordination between visions, goals, and strategies;

- Continuity of the planning system in the country;

- Plan executive's power and legal status;

- $\quad$ Explicit targets and transparency roles of plans;

- Plan Comprehensiveness;

- Periodical upgrading of the planning system;

- Decentralizing the decision-making authorities to the local government;

- Scoping toward the Standardization of urban life requirements

Finally, the selected countries determine the localized concepts for urban development plans in terms of their exclusive abilities, conditions, and functions.

\section{Preparation of Urban Development Plans}

In the last century, urban planning was majorly transformed in pioneer countries such as the United States, the United Kingdom and France, but the comprehensive planning method has however remained in several other countries, especially Asian and African (Zhang, 2006). Most nations had driven the urban planning system towards decentralization and participation by the alternative paradigms such as democratic planning, incremental planning, advocacy planning, and spatial strategic planning.

In this case, the United Kingdom government had prepared two types of plans including, (1) Structure Plan and (2) Local Plan, but these kind of plans had majorly been changed by the Planning and Compulsory Purchase Act from year 2004. This Act considers economic prosperity, social integration, and environmental protection as major objectives by employing effective elements such as public participation, integrated regulations, and a system-based plan. Furthermore, the Local Development Frameworks have been replaced as existing development plans which are known as Local Plans and Unitary Development Plans. The recent framework must be enclosed with policies, proposals, and other documents related to land use and spatial planning in adjoining areas (CPRE, 2011; Davoudi, 2006).

In another case, the United States have employed local planning since the beginning of the Nineteenth century, whilst the planning commission was being established and the Standard State Zoning Enabling Act (SZEA) was being enacted (Cullingworth \& Caves, 2009). The United States had a strong background in the preparation of urban development plans during the decades from 1940-1960, namely the General plan, the Master plan, and the City plan (Kaiser \& Godschalk, 1995).

Since 1960, environment and green spaces were emphasized based on the Federal Acts. These regulations were enacted to control urban land use with more flexibility and increase public participation in development plans. Thus, public sectors have participated at extensive levels such as by establishing local active councils (Tofigh et al., 2005).

In the Netherlands, the planning commission is delegated to be responsible for the spatial planning at the national level while the municipalities are in charge of the plan preparation (Larsson, 2006). Municipalities are independent in the urban development plans' process, but regional and central governments enable an integration plan (In passing plan) to be prepared whilst the land use zoning is outlined. Since 2008, the preparation of land use zoning plans became compulsory for all municipalities (Dutch Ministry of Infrastructure and the environment, 2011).

Unlike the Netherlands, the French government's system is characterized by large numbers of small communes (Wollmann, 2004). Thus, communes have delegated the preparation of urban development plans which are called SCOT and LUP, and the French government has reduced the interference in the urban planning due to its decentralization policy. Consequently, the multi-tiered participation has been promoted among communes, municipalities, and local communities, and subsequently spatial planning has been emphasized at local levels (Tofigh et al, 2005). 
The German government has a federal system divided by states with determined authorities in relation to spatial planning. Thus, autonomous bodies are recognized as being responsible for the preparation of local development plans. Normally, two types of development plans are prepared in Germany: the Flachennutzurgs Plan (F-plan) and the Bebauurgs Plan (B-plan).The F-plan includes the summary of land use and is obligatory for the executive authority which has prepared it. The B-Plan is recognized as a guiding plan for the construction progress, and is also compulsory for private individuals (JMLITT, 2011). The F-plan and the B-plan are proceeded through six stages including: preparatory, first phase in public participation, preparation of the draft plan, second phase of public participation, adoption and approval phase, and post-approval phase (Larsson, 2006). As one of the last countries to join the European region, Denmark's urban planning is identified by two major features, namely decentralization and public participation. In this system, municipalities are responsible for preparing the urban development plans which are organized according to the municipal strategies (Pucher \& Buehler, 2008). Since year 2000, the municipality has been authorized to revise earlier urban plans (Danish Ministry of the Environment, 2007).

The master plan as a framework in local planning may help conduct the urban development process and preserve natural resources such as forests, pasturages and agricultural lands (Naess, 2001). Moreover, the master plan determines detailed plan contents including land use, density, building construction, and public transportation in each district (Attwell, 2000). Normally, Danish master plans are prepared in six stages, including: preliminary debate, planning of the proposal, publication of the plan proposal, plan adaptation, publication, and administration of the plan (Danish Ministry of the Environment, 2007).

Looking at the Far East, Japan has been preparing urban development plans based on the zoning system since 1968. According to the 1968 Act, urban planning councils of municipalities are responsible for the preparation of plans, although using the cooperation of specialists of related ministries and agencies. In this case, social communities and people can participate in the draft plan preparation and in the plan review stage (Wakamatsu, 2001).

In Malaysia, the government has prepared three major plans at the national, state, and local scales. These plans are prepared attempting the fulfillment of Malaysia's Vision 2020. Thus, the national plan employed as the foundation has systematically indicated required elements. Besides, the government has enacted the Town and Country Planning Act since 1976, describing local plans and missions. Moreover, Act 1976 established the framework for the process of development plans at the local level. Local plans are prepared to achieve control and the determination of development, establishment of the democratic governance, and protection of citizen rights (Malaysian Federal Department of Town and Country Planning, 2010).

Generally, a review of countries' practices in preparation of their urban plans indicates several considerable factors in order to achieve optimum efficiency based on the respective countries' features. However, this paper reveals that said countries have transformed their preparation approaches in local plans according to the innovative methods which have focused on reducing the central government roles from main actor to mere supervisor.

Similarly, authorities have tried to enhance the connectivity among plans with upper and lower levels of preparation process in order to achieve perfect coordination with the planning system, and subsequently achieved equal development among various cities based on their exclusive conditions. Finally, the goals and strategies in urban development plans are determined based on the realistic views and executive abilities.

\section{Assessment of Urban Development Plans in Iran}

The current legal basis of urban planning is referred to the Establishment of Ministry of Housing and Urban Development Act from 1972 (Kamrava, 2007). Based on the 1972 Act, urban development plans were classified into three different categories, namely master plans, detailed plans and guidance plans, and were singularly defined in the Change Name Act. The master plan conceived as a long term urban plan is the main plan in a city (MHUD, 1992). It includes the structure and direction of the development, the urban capacity, and the regulations and criteria in various fields. The detailed plan is prepared for cities which had already approved master plans; therefore their components are detailed maps of the city's neighborhoods, the related regulations and criteria (MHUD, 2006). Finally, guiding plans conceived as short-term urban plans are prepared by the Ministry of Country in terms of the Agreement Twelve to solve critical urban problems in those cities without master plans. A guiding plan determines the population's density, per capita urban land uses, land use maps, and building regulations (AUDHC, 2010). The master plans are prepared through Agreement Twelve, based on the three major phases including the status quo, analysis, and suggestions.

Agreement Twelve is defined as an inflexible framework including services description to the preparation of 
urban development plans which is conclusive for all Iranian cities. However, the implementation of master plans for most Iranian cities should solve most of the problems within four decades, although a large amount of literature has given ample evidence that the achievements of master plans hardly correspond to the original goals and objectives when they are put into practice (Mashhoudi, 2001; Panahandeh et al., 2009; Zanganeh et al., 2011). In this case, such a situation is considered as a failure.

Iran's urban planning is based on the comprehensive planning method. This method relies on rationalism, holistic, and belief in progress (Friedmann, 1971). It is embodied in both the geometric and physical concepts. In a common way, goals of plans are decided by community managers and political representatives. Thus, the decision making and goal setting are not essentially resolved by comprehensive planning. Iran's master plans are considered as inflexible and unchangeable; According to a large body of literature, master plans based on the comprehensive planning method have met various criticisms whose defects are summarized in Table 2 (Cabral \& de Moura, 1996; Faludi, 1973; Friedmann, 1971; Halla, 2002; Panahandeh et al., 2009).

Table 2. Classification of comprehensive planning methods weaknesses

\begin{tabular}{ll}
\hline Domains & Weaknesses \\
\hline Theoretical & Prepared based on the rationalism, holistic, positivism, and functionalism; \\
& Lack of realistic view for supervision and intervention; \\
& Lock of appropriate attention to dynamism and complexity city's nature. Impossibility of \\
& forecasting; \\
& Ambiguous of urban planning knowledge among different sciences such as engineering, biology, \\
& and social science; \\
& To focus urban planning in physical planning and neglecting in urban design; \\
& Inattention to process of decision making, goals and policies setting; \\
& Lock of appropriate attention to goals for life quality, social justice, and indigenous values. \\
\hline Methods and & Plans are prepared and approved by methods which are prolonged, imperious, and up-down; \\
& Urban plans studies are in terms of the detailing, spreading, indirect, and causeless; \\
& Emphasis on quantitative methods, abstraction, and static; \\
& Lack of continuity among urban planning stages (preparation, executive, and management); \\
& Emphasis on quantitative indexes, artificial partitions, and patterns unification; \\
& To restrict future of development cities by land use maps which are inflexible and static frame; \\
& Lock of appropriate attention to features, desires and requests of local communities. \\
\hline Political assessments influence on urban development plans direction; \\
Inattention to obtainable facilities and executive instruments; \\
Lack of public participation and beneficiary groups in decision making and decision taking; \\
To transform urban development procedures as collections of administrative procedures and static \\
regulations; \\
Lock of appropriate attention to financial, technical, and organizational resources; \\
Lack of forecasting revision and improvement; \\
Lack of public participation and local facilities using in executive and management phase.
\end{tabular}

Source: Cabral and de Moura, 1996; Faludi, 1973; Friedmann, 1971; Halla, 2002; Panahandeh et al., 2009.

Accordingly, inefficiencies of the master plans caused the kick start of serious problems in Iranian cities, such as the birth of slum areas and uncontrolled development. Iran's cities experience various inefficiencies in their development process (Maghsoodi Tilaki et al., 2011). In order to help face this problem, this study has extrapolated the defects by means of analyzing the data collected with semi-structured interviews. The interviewees explained their opinions about different reasons behind the faults of the current urban development plans in Iran. These are categorized in four basic categories as presented in Table 3. 
Table 3. Categorization of recognized defects in Iran's urban development plans based on the interviewees opinions

\begin{tabular}{|c|c|c|}
\hline Phases & Weakness & Inefficiency source \\
\hline Content & $\begin{array}{l}\text { Lack of appropriate connection among social and economic aspect } \\
\text { with physical matters in urban development plans } \\
\text { Negligence from people and NGO requirements } \\
\text { Outlets of plan is presented by land use map with ideal situation } \\
\text { without alternative options } \\
\text { Lack of integrated and reliable data sources in urban planning process } \\
\text { process of urban development plans are inefficiency and inflexibility }\end{array}$ & $\begin{array}{l}\text { Legal } \\
\text { Structural } \\
\text { Planning } \\
\text { Structural } \\
\text { Planning } \\
\text { Legal } \\
\text { Planning } \\
\text { Structural } \\
\text { Structural } \\
\text { Legal } \\
\text { Structural }\end{array}$ \\
\hline $\begin{array}{l}\text { Coordination } \\
\text { and } \\
\text { consonance }\end{array}$ & $\begin{array}{l}\text { Urban planning system is sectoral } \\
\text { Governmental organizations Don not follow from Municipalities law } \\
\text { and regulations } \\
\text { Lack of coordination among municipality and authorities who related } \\
\text { in preparation and approval process } \\
\text { Lack of unique urban management in planning process } \\
\text { Lack of appropriate responsibilities in local authorities for } \\
\text { modification of plans in terms of the urban situation in short- term }\end{array}$ & $\begin{array}{l}\text { Legal } \\
\text { Administrative } \\
\text { Legal } \\
\text { Administrative } \\
\text { Legal } \\
\text { Planning } \\
\text { Legal } \\
\text { Structural } \\
\text { Legal } \\
\text { Structural }\end{array}$ \\
\hline $\begin{array}{l}\text { Stakeholders } \\
\text { Participation }\end{array}$ & $\begin{array}{l}\text { Ignorance of people opinions by authorities who related in preparation } \\
\text { and implementation of urban development process } \\
\text { Lack of participation by private sectors in implementation of urban } \\
\text { development plan process } \\
\text { Lack of compatibility among municipality organization with local } \\
\text { requirements }\end{array}$ & $\begin{array}{l}\text { Legal } \\
\text { Planning } \\
\text { Structural } \\
\text { Legal } \\
\text { Administrative } \\
\text { Structural } \\
\text { Administrative } \\
\text { Legal } \\
\text { Administrative }\end{array}$ \\
\hline $\begin{array}{l}\text { Plans abilities } \\
\text { and Feasibility }\end{array}$ & $\begin{array}{l}\text { Lack of evaluation in process of urban development plans } \\
\text { Lack of appropriate financial resources in implementation of urban } \\
\text { development process } \\
\text { Inefficiency of municipality in implementation of urban development } \\
\text { plans } \\
\text { Incompatibility of municipality organizational structure for } \\
\text { implementation of urban development process } \\
\text { Suggestions of urban development plans are ambitious }\end{array}$ & $\begin{array}{l}\text { Administrative } \\
\text { Structural } \\
\text { Financial } \\
\text { Administrative } \\
\text { Structural } \\
\text { Administrative }\end{array}$ \\
\hline
\end{tabular}

Source: Authors' work.

\section{Learned Lessons}

Urban development plans are transformed to be most efficient in different aspects of cities' development control. This transformation has advanced in terms of the changes in the urban planning concepts and the plan's preparation process. The selected countries could resolve their major city problems by employing different strategies. Those successful transformations may be useful to help improve urban planning mechanisms in other countries like Iran. Hence, this paper emphasizes on the major learned lessons at the present stage which have been extrapolated from the selected countries' review.

\subsection{Theoretical Method}

Basically, a city's nature of dynamism and complexity, a highly desired feature for the fulfillment of people's social needs, are not well adapted in the comprehensive plans which mostly focus on long term planning rather 
than short term effects. To be more effective, urban development plans and urban planning processes may be changed from linear to cyclical patterns. The cyclical pattern has been developed from the application of the system theory's approach in urban planning, and subsequently some planning principles have been changed. The selected countries conducted an urban planning system in order to establish a decision-making and a decision-taking phase separately; this strategy was never before considered by Iranian urban planning authorities as they have mostly employed a comprehensive planning approach. Consequently, the system theory could resolve some basic issues of urban planning, including the coherence between the goals and the process of preparation through sufficient decisions made by the decision makers.

\subsection{Socio-Economic Aspects of Urban Planning}

Basically, the socio-economic aspects have never been minimally considered in the Iranian city planning context. The same situation was prevalent in the selected countries during the 1960s and through the 1970s, but such nations have transformed their urban planning methods in order to reduce the inefficiencies found in previous planning of cities. Thus, recently, objectives are considered in social fields such as social welfare, quality of life, and social equity. An urban planning approach such as the spatial strategic planning is able to realize its objectives, while a comprehensive planning method cannot adapt to them. Thus, Iranian urban planning cannot attempt to consider other aspects of cities because it was created from a static framework, only focused on the physical aspects of the city.

\subsection{Local Management and Community Contribution}

In Iran, the division of task management cannot be recognized at different levels within the government. This situation is especially seen in the urban planning mechanism, because of the centralization of Iran's government. In contrast, the selected countries have considered different levels of authorities to achieve more collaboration and participation in the planning process. Local authorities and people's participation are identified as one of the fundamental inputs for the successful process of urban planning in different countries. Urban planning based on the comprehensive planning method cannot eliminate this inefficiency already prevailing in Iranian cities, while different countries have resorted to involve local communities for various reasons, such as to help prevent the birth of holism and assimilating various solutions to mitigate cities' issues.

Urban planning in selected countries could make use of public participation to establish public trust in the development progress, advance social solidarity and motivation to cooperate, make efficient use of public facilities and private sources, and also reduce centralization. On the other hand, the growth of public participation in Iran's urban management has met various barriers due to the lack of an appropriate legislation, the lack of a clear definition for public participation positions in institutional tasks, and the disproportionate growth of Non-Governmental Organizations.

\subsection{Realism versus Idealism}

Master plans' goals are ideally determined through the comprehensive planning approach. Consequently, the idealism of Iranian master plans is the main cause of the nonexistent implementation to the given suggestions in the last five decades. In contrast, experiences of selected countries have revealed that the associated authorities have replaced realistic viewpoints with the idealistic stance in determining the goals and strategies for urban development plans. This transformation can occur by employing appropriate methods such as a system approach to urban planning. Indeed, recent global changes of urban development plans have indicated that the strategies have to be decided in the direction of determined visions, and subsequently based on the actuality of the requirements, issues and facilities to achieve such visions.

\subsection{Flexibility Instead of Inflexibility}

Static urban development plans cannot be effective to control the cities' growth due to the complexity, functioning, and the immediate changes of cities. Iran's master plans have been prepared through inflexible patterns, while flexible elements can support urban development plans in order to continuously meet local people's requirements and expectations continuously. Practically, Iranian master plans are influenced by Agreement Twelve as similar services' description in the preparation of such plans for all cities of Iran, but other examples coming from other countries such as France and Denmark have indicated that the city council only prepares urban development plans in the direction of the central government's vision. Consequently, Iran's Agreement Twelve as a services' description should be changed in order to be more adherent to the guidelines' procedures causing master plans to be prepared in compliance with the specific situations and abilities of different cities.

Additionally, the syllabus of studies used in preparation of master plans should be determined by exclusive 
conditions of cities based on the significance of different fields for each city. By contrast, Iran's Agreement Twelve has defined a singular syllabus to be reviewed and studied during the preparation stage of urban development plans for all Iranian cities. Additionally, studying the approach is another effective strategy for the preparation of urban development plans, as it may influence the consequential effects of city planning, especially when such studying approaches lean towards an improved flexibility.

\section{Findings and Recommendations}

This paper indicated that several factors may be revised to improve the current process of urban development plans by employing upgraded methods or neo-techniques similar to those observed in other countries. Different approaches in various countries cannot completely be matched due to the different predominant features of each country. Therefore, the selective procedure should be localized in the direction of Iranian urban planning system based on the exclusive situations and conditions of the different Iranian cities. The review of approaches and perspectives revealed effective actions in contrast of each weakness. Hence, this paper merges useful functions found in the selected countries with Iran's urban development plan weaknesses in Table 4. As illustrated in Table 4, the defects of Iran's urban development plans can be improved based on the appropriate functions as extrapolated from other countries' experiences as mentioned previously in this paper.

Table 4. Weakness of urban development plans and introduction improvement suggestion based world experiences

\begin{tabular}{|c|c|c|c|c|}
\hline Phases & Weakness & $\begin{array}{l}\text { Inefficiency } \\
\text { source }\end{array}$ & $\begin{array}{l}\text { Alternative option } \\
\text { according world } \\
\text { experiences and evaluated } \\
\text { methods and techniques } \\
\text { of urban planning }\end{array}$ & $\begin{array}{l}\text { Recommendation for } \\
\text { Improvement }\end{array}$ \\
\hline \multirow[t]{6}{*}{ Content } & $\begin{array}{l}\text { Inconsideration to } \\
\text { exclusive conditions } \\
\text { of each city }\end{array}$ & $\begin{array}{l}\text { Legal } \\
\text { Structural }\end{array}$ & $\begin{array}{l}\text { Abolishment of plan } \\
\text { preparation by definitive } \\
\text { agreement or static } \\
\text { framework }\end{array}$ & $\begin{array}{l}\text { Change definitive } \\
\text { agreement (Agreement } \\
\text { Twelve) toward guideline } \\
\text { including presentation of } \\
\text { proceeds of stages }\end{array}$ \\
\hline & $\begin{array}{l}\text { Lack of appropriate } \\
\text { connection among } \\
\text { social and economic } \\
\text { aspect with physical } \\
\text { matters in urban } \\
\text { development plans }\end{array}$ & $\begin{array}{l}\text { Planning } \\
\text { Structural }\end{array}$ & $\begin{array}{l}\text { Transform urban planning } \\
\text { system toward urban } \\
\text { planning method based } \\
\text { on the system approach }\end{array}$ & $\begin{array}{l}\text { Comprehensive planning } \\
\text { method should be } \\
\text { transformed to spatial } \\
\text { strategic planning }\end{array}$ \\
\hline & $\begin{array}{l}\text { Negligence from } \\
\text { people and NGO } \\
\text { requirements }\end{array}$ & $\begin{array}{l}\text { Planning } \\
\text { Legal }\end{array}$ & $\begin{array}{l}\text { Establish position to } \\
\text { hearing people and NGO } \\
\text { recommendation after } \\
\text { draft preparation and } \\
\text { before final approval }\end{array}$ & $\begin{array}{l}\text { Change process of plan } \\
\text { preparation to create } \\
\text { legal position for people } \\
\text { participation }\end{array}$ \\
\hline & $\begin{array}{l}\text { Outlets of plan is } \\
\text { presented by land } \\
\text { use map with ideal } \\
\text { situation without } \\
\text { alternative options }\end{array}$ & $\begin{array}{l}\text { Planning } \\
\text { Structural }\end{array}$ & $\begin{array}{l}\text { Urban development plans } \\
\text { present goals, and then } \\
\text { policies and strategies to } \\
\text { achieve }\end{array}$ & $\begin{array}{l}\text { Transform urban planning } \\
\text { method and connection } \\
\text { among issues, suggestions } \\
\text { and abilities with choice } \\
\text { of alternative options }\end{array}$ \\
\hline & $\begin{array}{l}\text { Lack of integrated } \\
\text { and reliable data } \\
\text { sources in urban } \\
\text { planning process }\end{array}$ & Structural & $\begin{array}{l}\text { Clear, reliable, and } \\
\text { available data from } \\
\text { sources which collected } \\
\text { by professional agencies } \\
\text { of organizations to } \\
\text { employ in scientific } \\
\text { research or practical } \\
\text { projects }\end{array}$ & $\begin{array}{l}\text { Determine authority for } \\
\text { data collection in process } \\
\text { of preparation urban } \\
\text { development plans and } \\
\text { prevent to estimate in } \\
\text { basic data }\end{array}$ \\
\hline & $\begin{array}{l}\text { process of urban } \\
\text { development plans } \\
\text { are inefficiency and } \\
\text { inflexibility }\end{array}$ & $\begin{array}{l}\text { Legal } \\
\text { Structural }\end{array}$ & $\begin{array}{l}\text { Participation of related } \\
\text { stakeholders in process of } \\
\text { plan/ separate process to } \\
\text { major phases including } \\
\text { decision making and }\end{array}$ & $\begin{array}{l}\text { Flexibility and efficiency } \\
\text { of plan by public } \\
\text { participation, change } \\
\text { concepts of plans, and } \\
\text { prevent detailing and }\end{array}$ \\
\hline
\end{tabular}




\begin{tabular}{|c|c|c|c|}
\hline & & & decision taking \\
\hline \multirow[t]{2}{*}{$\begin{array}{l}\text { Coordination } \\
\text { and } \\
\text { consonance }\end{array}$} & $\begin{array}{l}\text { Urban planning } \\
\text { system is sectoral }\end{array}$ & $\begin{array}{l}\text { Legal } \\
\text { Administrative }\end{array}$ & $\begin{array}{l}\text { Employing spatial } \\
\text { strategic planning/ } \\
\text { Connection with upper } \\
\text { and lower levels of } \\
\text { planning/ Participation of } \\
\text { related stakeholders/ } \\
\text { change planning method }\end{array}$ \\
\hline & $\begin{array}{l}\text { Governmental } \\
\text { organizations Don } \\
\text { not follow from } \\
\text { Municipalities law } \\
\text { and regulations }\end{array}$ & $\begin{array}{l}\text { Legal } \\
\text { Administrative }\end{array}$ & $\begin{array}{l}\text { Each authority has own } \\
\text { responsibilities in } \\
\text { planning process or urban } \\
\text { tasks which is obliged to } \\
\text { precede them }\end{array}$ \\
\hline
\end{tabular}

definitive decisions

Change urban planning method toward spatial strategic planning / enact comprehensive law of urban development / connection with other levels of planning Removal of conflict among different laws/ describe clear position of municipality in city/ strong connection among city council, other governmental agencies and offices

\begin{tabular}{ll}
\hline Lack of & Legal \\
coordination among & Planning \\
municipality and & \\
authorities who & \\
related in & \\
preparation and & \\
approval process &
\end{tabular}

\begin{tabular}{|c|c|}
\hline $\begin{array}{l}\text { Integration planning } \\
\text { process / participation of } \\
\text { municipality in } \\
\text { preparation and approval } \\
\text { process / legal support to } \\
\text { strong participation of } \\
\text { municipality in planning } \\
\text { process }\end{array}$ & $\begin{array}{l}\text { Modification of Laws and } \\
\text { regulations to establish } \\
\text { position for municipality/ } \\
\text { change plan preparation } \\
\text { authority from MHUD to } \\
\text { municipality/ connection } \\
\text { different stages in urban } \\
\text { planning process }\end{array}$ \\
\hline $\begin{array}{l}\text { Unique urban } \\
\text { management in city to } \\
\text { concentrate development } \\
\text { strategies and policies }\end{array}$ & $\begin{array}{l}\text { Change of current } \\
\text { situation and definition } \\
\text { municipality as urban } \\
\text { management }\end{array}$ \\
\hline
\end{tabular}

\begin{tabular}{ll}
\hline Lack of unique & Legal \\
urban management & Structura \\
in planning process &
\end{tabular}
and then achievement of goals

\begin{tabular}{|c|c|c|c|c|}
\hline & & & \\
\hline & $\begin{array}{l}\text { Lack of appropriate } \\
\text { responsibilities in } \\
\text { local authorities for } \\
\text { modification of } \\
\text { plans in terms of the } \\
\text { urban situation in } \\
\text { short- term }\end{array}$ & $\begin{array}{l}\text { Legal } \\
\text { Structural }\end{array}$ & $\begin{array}{l}\text { Change process of } \\
\text { decision making / } \\
\text { reducing of central } \\
\text { government } \\
\text { responsibilities/ } \\
\text { decentralization strategy }\end{array}$ & $\begin{array}{l}\text { Change of laws and } \\
\text { regulations to } \\
\text { decentralization and then } \\
\text { shift responsibilities from } \\
\text { central government to } \\
\text { provincial and urban } \\
\text { levels }\end{array}$ \\
\hline \multirow[t]{4}{*}{$\begin{array}{l}\text { Stakeholders } \\
\text { Participation }\end{array}$} & $\begin{array}{l}\text { Iran's urban } \\
\text { planning mechanism } \\
\text { is top-down. }\end{array}$ & $\begin{array}{l}\text { Legal } \\
\text { Planning } \\
\text { Structural }\end{array}$ & $\begin{array}{l}\text { Establishment of cycle } \\
\text { process as linear pattern } \\
\text { in urban planning }\end{array}$ & $\begin{array}{l}\text { Change of urban planning } \\
\text { method/ establishment of } \\
\text { decision making and } \\
\text { decision taking phases }\end{array}$ \\
\hline & $\begin{array}{l}\text { Ignorance of people } \\
\text { opinions by } \\
\text { authorities who } \\
\text { related in } \\
\text { preparation and } \\
\text { implementation of } \\
\text { urban development } \\
\text { process }\end{array}$ & $\begin{array}{l}\text { Legal } \\
\text { Administrative }\end{array}$ & $\begin{array}{l}\text { Establishment of } \\
\text { participation mechanism } \\
\text { regarding spatial strategic } \\
\text { planning }\end{array}$ & $\begin{array}{l}\text { Change of legal status and } \\
\text { establishment of } \\
\text { appropriate mechanism to } \\
\text { know people opinions and } \\
\text { suggestions }\end{array}$ \\
\hline & $\begin{array}{l}\text { Lack of } \\
\text { participation by } \\
\text { private sectors in } \\
\text { implementation of } \\
\text { urban development } \\
\text { plan process } \\
\end{array}$ & $\begin{array}{l}\text { Structural } \\
\text { Administrative }\end{array}$ & $\begin{array}{l}\text { Private developers as } \\
\text { executive instrument help } \\
\text { urban management to } \\
\text { achieve plan suggestions }\end{array}$ & $\begin{array}{l}\text { Change Urban } \\
\text { management viewpoint/ } \\
\text { Responsibilities and } \\
\text { authorities each } \\
\text { component is defined in } \\
\text { implementation process }\end{array}$ \\
\hline & $\begin{array}{l}\text { Lack of } \\
\text { compatibility among } \\
\text { municipality } \\
\text { organization with } \\
\text { local requirements } \\
\end{array}$ & $\begin{array}{l}\text { Legal } \\
\text { Administrative }\end{array}$ & $\begin{array}{l}\text { Participation NGO and } \\
\text { people in executive } \\
\text { activities voluntary }\end{array}$ & $\begin{array}{l}\text { Appropriate authorities to } \\
\text { develop municipality } \\
\text { organization based on the } \\
\text { abilities and strength of } \\
\text { cities / encourage and }\end{array}$ \\
\hline
\end{tabular}


involve urban agencies, NGO, and active people to participant and support municipalities' executive functions

\begin{tabular}{|c|c|c|c|}
\hline $\begin{array}{l}\text { Plans abilities } \\
\text { and } \\
\text { Feasibility }\end{array}$ & $\begin{array}{l}\text { Lack of evaluation } \\
\text { in process of urban } \\
\text { development plans }\end{array}$ & $\begin{array}{l}\text { Administrative } \\
\text { Structural }\end{array}$ & $\begin{array}{l}\text { Establish evaluation stage } \\
\text { in process of urban } \\
\text { development plans by } \\
\text { spatial strategic planning }\end{array}$ \\
\hline
\end{tabular}

Consider to evaluation stage in process of urban planning by add-on functions or change method of planning toward spatial strategic planning

\begin{tabular}{|c|c|c|c|}
\hline $\begin{array}{l}\text { Lack of appropriate } \\
\text { financial resources } \\
\text { in implementation } \\
\text { of urban } \\
\text { development } \\
\text { process }\end{array}$ & Financial & $\begin{array}{l}\text { Investment by private } \\
\text { sectors/ financial } \\
\text { planning attached to } \\
\text { urban development plan/ } \\
\text { division of financial } \\
\text { resources between } \\
\text { implementation of plans } \\
\text { and other activities of } \\
\text { municipality }\end{array}$ & $\begin{array}{l}\text { Consider to private sector/ } \\
\text { preparation of financial } \\
\text { planning / consider to } \\
\text { value-added by } \\
\text { implementation of plan }\end{array}$ \\
\hline $\begin{array}{l}\text { Inefficiency of } \\
\text { municipality in } \\
\text { implementation of } \\
\text { urban development } \\
\text { plans }\end{array}$ & $\begin{array}{l}\text { Administrative } \\
\text { Structural }\end{array}$ & $\begin{array}{l}\text { Goals are determined } \\
\text { based on the requirements } \\
\text { of people and } \\
\text { municipality abilities/ } \\
\text { municipality are } \\
\text { responsible against } \\
\text { people }\end{array}$ & $\begin{array}{l}\text { Recognize technical } \\
\text { abilities and human } \\
\text { resources/ determination } \\
\text { clear executive } \\
\text { mechanism in } \\
\text { municipalities/ definition } \\
\text { of agencies missions in } \\
\text { implementation of plans }\end{array}$ \\
\hline $\begin{array}{l}\text { Incompatibility of } \\
\text { municipality } \\
\text { organizational } \\
\text { structure for } \\
\text { implementation of } \\
\text { urban development } \\
\text { process }\end{array}$ & Administrative & $\begin{array}{l}\text { Integration of preparation } \\
\text { process and } \\
\text { implementation/goals are } \\
\text { determined in directions } \\
\text { of abilities of } \\
\text { municipalities and city. }\end{array}$ & $\begin{array}{l}\text { Involve municipalities in } \\
\text { preparation and approval } \\
\text { process/ determination of } \\
\text { goals based on the reality } \\
\text { abilities of municipalities }\end{array}$ \\
\hline $\begin{array}{l}\text { Suggestions of } \\
\text { urban development } \\
\text { plans are ambitious }\end{array}$ & Planning & $\begin{array}{l}\text { Goals, strategies and } \\
\text { policies are determined } \\
\text { based on abilities and } \\
\text { requirements by } \\
\text { integration and strong } \\
\text { linkage }\end{array}$ & $\begin{array}{l}\text { Connection between real } \\
\text { abilities, common } \\
\text { requirements and goals / } \\
\text { Establish cycle planning } \\
\text { system/ consider to } \\
\text { feedback and evolution }\end{array}$ \\
\hline
\end{tabular}

Source: Authors' work.

\section{Acknowledgement}

The authors would like to thank the Universiti Sains Malaysia for providing financial support for this study.

\section{References}

Attwell, K. (2000). Urban Land Resources and Urban Planting--Case Studies from Denmark. Landscape and Urban Planning, 52(2-3), 145-163. http://dx.doi.org/10.1016/S0169-2046(00)00129-8

AUDHC. (2010). Approved Collection Report: Architecture \& Urban Development High Council. Tehran: Nashr e tosehe, 2010.

Basiago, A. D. (1998). Economic, Social, and Environmental Sustainability in Development Theory and Urban Planning Practice. The Environmentalist, 19(2), 145-161. http://dx.doi.org/10.1023/A:1006697118620

Cabral, J. T., \& de Moura, A. S. (1996). City Management, Local Power, and Social Practice. Latin American Perspectives, 23(4), 54-70. http://dx.doi.org/10.1177/0094582X9602300405

Chaker, A., K. El-Fadl, Chamas, L., \& Hatjian, B. (2006). A Review of Strategic Environmental Assessment in 
12 Selected Countries. Environmental Impact Assessment Review, 26(1), 15-56. http://dx.doi.org/10.1016/j.eiar.2004.09.010

Clarke, J. I., Fisher, W. B., \& Bowen-Jones, H. (1981). Change and Development in the Middle East: Essays in Honour of Wb Fisher. London ; New York: Methuen, 1981.

CPRE. Planning Help: Campaign to Protect Rural Engeland. CPRE. (2012). Retrieved December 20, 2013, from http://www.planninghelp.org.uk/planning-system/local-development-frameworks

Cullingworth, J. B., \& Caves, R. W. (2009). Planning in the USA: Policies, Issues and Processes (3rd ed.). New York: Routledge, 2009.

Danish Ministry of the Environment. (2007). Spatial Planning in Denmark. Copenhagen: Ministry of the Environment, 2007.

Davoudi, S. Evidence-Based Planning. (2006). Rhetoric and Reality. DISP, 42(165), 14-24.

De Graaf, R. S., \& Dewulf, G. P. M. R. (2010). Applying the Lessons of Strategic Urban Planning Learned in the Developing World to the Netherlands: A Case Study of Three Industrial Area Development Projects. Habitat International, 34(4), 471-477. http://dx.doi.org/10.1016/j.habitatint.2010.02.005

Dutch Ministry of Infrastructure and the environment. Roles and Responsibilities Other Authorities (2013). Retrieved December 21, 2013, from http://english.verkeerenwaterstaat.nl/ english/topics/spatial-planning/roles_and_responsibilities_other_authorities/

Fainstein, S. S. (1991). Promoting Economic Development Urban Planning in the United States and Great Britain. Journal of the American Planning Association, 57(1), 22-33. http://dx.doi.org/10.1080/01944369108975469

Faludi, A. (1973). Planning Theory. Oxford: Pergamon Pr, 1973.

Ferdowsian, F. (2002). Modern and Traditional Urban Design Concepts and Principles in Iran. PhD, University of Stuttgart.

Friedmann, J. (1971). The Future of Comprehensive Urban Planning: A Critique. Public Administration Review, 31(3), 315-326. http://dx.doi.org/10.2307/974890

Halla, F. (2002). Preparation and Implementation of a General Planning Scheme in Tanzania: Kahama Strategic Urban Development Planning Framework. Habitat International, 26(2), $281-293$. http://dx.doi.org/10.1016/S0197-3975(01)00051-0

Indian Local Government. (2011). Administrative Hierarchy According to Indian Constitution. Retrieved from http://opengov.in/wp/2011/04/administrative-hierarchy-according-to-indian-constitution/

Japanese Ministry of Land, Infrastructure, Transport and Tourism (JMLITT). (2012). An Overriew of Spatial Policy in Asian and European Countries: Japanese Ministry of Land, Infrastructure, Transport and Tourism. Retrieved December 15, 2013, from http://www.mlit.go.jp/kokudokeikaku/international/spw/index_e.html

Kaiser, E. J., \& David, R. G. (1995). Twentieth Century Land Use Planning. Journal of Amrican Planning Associaition, 61(3), 365-385. http://dx.doi.org/10.1080/01944369508975648

Kamrava, M. A. (2007). Introduction to Contemporary Town Planning in Iran. Edited by 2739. Tehran: University of Tehran Press, 2007.

Karshenas, M. (1990). Oil, State, and Industrialization in Iran. Cambridge: Cambridge Univ Pr, 1990.

Larsson, G. (2006). Spatial Planning Systems in Western Europe: An Overview. Amsterdam: IOS Press 2006.

Madanipour, A. (2003). Tehran: The Making of a Metropolis. Tehran: Pardazesh Publication.

Maghsoodi Tilaki, M. J., Mustafa, R. A., Marzbali, M. H., Abdullah, A., \& Ariffin, J. (2011). Challenges of the Informal Settlements in Developing Countries' Cities: A Case Study of Iran. World Applied Sciences Journal, 12(2), 160-169.

Malaysian Federal Department of Town and Country Planning. (2010). National Physical Plan-2. Kuala Lumpur: Federal Department of Town and Country Planning.

Mashhoudi, S. (2001). The Principles of Fluid Urban Plans. Tehran: Organization of Urban Planning and Processing Press.

MHUD. (1992). Enacted Regulations Collection. Tehran: Ministry of Housing and Urban Development. 
MHUD. (2006). World Experiences in Urban Strategic Planning. Tehran: Ministry of Housing and Urban Development.

Mumford, E. (1992). Ciam Urbanism after the Athens Charter. Planning Perspectives, 7(4), 391-417. http://dx.doi.org/10.1080/02665439208725757

Naess, P. (2001). Urban Planning and Sustainable Development. European Planning Studies, 9(4), 503-24. http://dx.doi.org/10.1080/713666490

Panahandeh Khah, M., Farhoodi, R., M. Gharakhlou, N., \& Ghadami, M. (2009). A Critique of the Prevailing Comprehensive Urban Planning Paradigm in Iran: The Need for Strategic Planning. Planning Theory, 8(4), 335-361. http://dx.doi.org/10.1177/1473095209341328

Pucher, J., \& Buehler, R. (2008). Making Cycling Irresistible: Lessons from the Netherlands, Denmark and Germany. Transport Reviews, 28(4), 495-528. http://dx.doi.org/10.1080/01441640701806612

Rahnama, M. R. (2008). Study in Urban Detailed Plans. Mashhad: Jahad-e-Daneshgahi.

Ramli, R., \& Azadehdel, A (2009). Administrative Reform in Guilan Province, Iran: An Analysis of Advantages and Shortcomings. AKADEMIKA, 75, 65-84.

Statistical Center of Iran. Public Census. (2006). Tehran, Iran: Statistical Center of Iran, 2006.

Tang, W. S. (2000). Chinese Urban Planning at Fifty: An Assessment of the Planning Theory Literature. Journal of Planning Literature, 14(3), 347. http://dx.doi.org/10.1177/08854120022092700

Tofigh, Firouz., A. (2005). Madanipoor, and S. Davoudi. Contemporary Urban Planning Methodes. Tehran: Center for Architectural \& Urban Studies and Research, 2005.

Wollmann, H. (2004). Local Government Reforms in Great Britain, Sweden, Germany and France: Between Multi-Function and Single-Purpose Organisations. Local Government Studies, 30(4), 639-665. http://dx.doi.org/10.1080/0300393042000318030

World Bank. (2010). Retrieved October 11, 2013, from http://data.worldbank.org/about/country-classifications/ country-and-lending-groups

Zanganeh S. S., Sauri, D., Serra, P., Modugno, S., Seifolddini, F., \& Pourahmad, A. (2011). Urban Sprawl Pattern and Land-Use Change Detection in Yazd, Iran. Habitat International, 35(4), 521-528. http://dx.doi.org/10.1016/j.habitatint.2011.02.004

Zhang, T. (2006). Beyond Metropolis: The Planning and Governance of Asia's Mega-Urban Regions. Journal of Planning Education and Research, 25(3), 333-334. http://dx.doi.org/10.1177/0739456X05285897

Ziari, K. (2006). The Planning and Functioning of New Towns in Iran. Cities, 23(6), 412-422. http://dx.doi.org/10.1016/j.cities.2006.08.006

\section{Copyrights}

Copyright for this article is retained by the author(s), with first publication rights granted to the journal.

This is an open-access article distributed under the terms and conditions of the Creative Commons Attribution license (http://creativecommons.org/licenses/by/3.0/). 